\title{
Loneliness in Artistic Expression
}

\author{
Marzanna Morozewicz \\ University of Bialystok, Poland \\ E-mail address: mamo3@wp.pl
}

ARTICLE INFO

\section{Keywords:}

Creation

Loneliness

Artistic expression

\section{Article history:}

Received 10 November 2018

Received in revised form 20 December 2018

Accepted 20 November 2019

ISSN: 2354-0036

DOI: 10.1515/ctra-2019-0016
A B S TR A C T

Delving into the nature of the creative process, attention is given in the article to particular kinds of emotions appearing in the course of the work of a creative person. Particular emphasis is given to the emotions the artist is guided by during the act of creation. The reflections presented in the text result not only from theoretical analysis, but also from the author's experience in the process of creation. In this context they refer closely to the personal emotional sensations accompanying the author when painting pictures.

The article distinguishes and analizes the concept of loneliness in artistic creation. Selected visual artists are recalled who deliberately refer in their work to the experience of loneliness in the process of creation. The significance of artists belonging to creative community groups is also pointed out. Positive and negative aspects of experiencing loneliness by the creator in the act of artistic creation are also stressed.

Artistic expression or scientific activity are a unique phenomenon in society. The creative process is a mental process necessary in the life of an individual. Human creativity, if it does arise, is accompanied by a number of complex experiences. While delving into the nature of the creative process I would like to point to the kind of emotions appearing during the course of work of a creative person. In particular, I would like to emphasize the emotions the artist is guided by during the act of creation. My observations concerning this issue are, to a large extent, based on my own experience in this respect.

The emotional layer of creativity encompasses two categories of sensations: those which are an inherent component of the creative process and those which are a side effect or result of the same process. Loneliness is an emotional state which, undoubtedly, belongs to both these categories. It results from the fact that the created work or idea is new and thus, not created by anyone so far. Hence, the creator is the only and also a lonely person for whom their own work is a complete and understandable creation. 
Loneliness during the creative process, isolation necessary to focus, lack of support and understanding by recipients is often an internal sensation giving the creator-artist a strong feeling of isolation.

Types of loneliness are manifold (Gadacz, 1995). Kępiński (2014) wrote about metaphysical loneliness, that is the loneliness in relation to the big world. Erich Fromm (2001) talked about the loneliness of existence as every man is a separate and unique individual. Schopenhauer (2000) wrote about mental loneliness caused by, for example, the loss of a close person. The same author analyzed physical loneliness, that is isolation. Moral loneliness is a lack of connection with values, symbols and models to follow. It is an internal spiritual emptiness. This kind of loneliness was dealt with in detail by Fromm in his works. Szczepański (1984) in turn wrote about the loneliness of dying as an ideal state of loneliness, being the ultimate silence.

I think that the loneliness of creation should be added to the above types of loneliness. It is a category which almost goes unnoticed, but is extremely important.

The sense of "being lonely" is one of the main feelings accompanying the creative artistic process. It may even be the essence of the creative act. In view of the above it is certain that loneliness belongs to the artist.

Loneliness of the creator understood as being just with oneself in the process of creation may become a source of wisdom, new strength and sometimes relief. Voluntary isolation is an autonomous experience, but not always self-sufficient and ensuring full satisfaction. After all, it does not take place in a void. The loneliness of the creator may be continuously disturbed from the outside. As a result forms of behaviour are evoked which become a kind of "safety valve" for their author. At that moment a question about the value and real creativity of the produced work arises. Does the creative process in this context have a therapeutic role, with the idea or work of art being only tools? If so, there is no genuine creativity here. Such effects of man's activity just reveal his suffering and help to relieve his internal tensions and conflicts. However, they have nothing to do with authentic creation. I think that real creative work is not born of suffering caused by external isolation, but the comfort of internal loneliness.

If the material or ideological expression of man may be a kind of self-therapy there arises the question of the genuine creativity of contemporary "primitive artists". Painting pictures or sculpting by the so-called "naive artists" is most frequently a reaction to the feeling of isolation and alienation (Piwocki, 1980). The painting of the Georgian artist Niko Pirosmanishvili or the works of Maria Korsak are a result of the self-therapy process. Thus naive painting seems to be a kind of therapy through artistic activity rather than through artistic expression as such. 
The artists called "inner necessity artists" are already creative in their productions. Henri Rousseau known as the Customs Officer, Teofil Ociepka or Nikifor Krynicki talk about their loneliness through their pictures. Their paintings are unrestrained expressions, a kind of dream and confession at the same time. These artists will be called creators, because they create on account of their "inner need" and to eliminate or curtail this need.

Not only the "inner necessity artists" talk about isolation in their creations. The awareness of one's loneliness may also be observed as one of the pillars of artistic identity present in so-called professional artists. In his paintings Jarosław Modzelewski seems to celebrate his loneliness. The artist tries to connect with the world using the language of pictures. In effect his paintings are auto-thematic treaties (Gorczyca, 1997). The artist incessantly contemplates whether art is a safe refuge for the creator or sentences him to loneliness. The human character in Modzelewski's paintings is entangled in activity, lost in the surrounding objects and feels physically lonely. Animal characters in his painting are usually perceived as "objects" of isolation. Modzelewski himself emphasizes very strongly his own loneliness in his expressions. He seems to be convinced that nobody needs his artistic creations; they do not serve any purpose and thus, thanks to loneliness, they are free. The creative process taking place when painting a picture is a peculiar type of empathy for the artist. Modzelewski feels and at the same time finds his place in his own creative works. He identifies himself with his work and puts his personal sensations and emotions into it. The unpredictably lonely artist participates in the event which turns out to be an encounter with his own artistic work. It is possible that the loneliness determining his creative process finally leads to a new experience, which is an intimate encounter of the author with his own creation.

It is worth considering if a similar intimacy of encounter exists when a work of art is the effect of collective creation (by a few authors). There is no denying that there are artistic activities or productions with the participation of several creators. They work together, so they are not physically lonely. The willingness to counteract creative loneliness becomes one of the reasons for establishing artistic groups. The feeling of belonging to a creative community may be supporting and enriching for the artist. Being associated with a group gives an opportunity for many intellectual contacts, an internal exchange of thoughts and finally, a search for common style, idea or forms of work. Acting in a group may have the form of a close relationship based on cooperation and similar opinions. It may unite a few or a dozen artists participating in group expositions and holding similar views on art. 
A popular Polish performer Zbigniew Warpechowski, in his statement about the avant-garde of art said that the avant-garde artist more than any other artist has to cope with his loneliness. Warpechowski (1996) says: Ioneliness "is neither sad nor sentimental, but is a necessity. Striving ahead we suddenly realise that we are alone and everybody else is somewhere at the back."

The artists taking part in new movements ideologically ahead of their time undoubtedly are faced with creative loneliness. Art avant-gardes formed and still form artistic groups organizing their own events or publishing manifestos in their own bulletins (e.g. Dada groups in 1919). Belonging to a group may be understood here as another kind of encounter resulting from creative loneliness.

Counteracting loneliness in creation does not need to have such an "institutionalized" form as that represented by artistic groups. The search for intellectual community is effective even through a casual exchange of thoughts, like that at a table in a cafe. The artist identifying with gypsy and bohemian circles finds in this community the possibility of expressing his protest against propriety, social norms or current aesthetic views. We may find a lot of examples of artists' involvement in, for instance, the Parisian Romantic Bohemia or later existentialism, and in Poland, for example, in the Young Poland's Cracow Bohemia. Independent artistic groups usually gathered in selected places (e.g. "Jama Michalikowa" in Cracow) or in particular quarters of a city. The artists' need for proximity made them settle down and work in the regions they viewed as their own. In Paris Montmartre and Montparnasse and in Berlin - Charlottenburg, and currently Mitte districts were such places. In New York ateliers, workshops and galleries are centred in the districts of Soho and Greenwich Village and in London in the area of, for instance, Old Bond or Cork Street.

I think that for the creator, being part of the bohemian movement is associated with the need for acceptance and prevention of destructive physical isolation. Collective productions or participation in the work of a group may in some cases turn out to be a valuable encounter enhancing the creativity of an artist.

The presented thoughts do not only result from theoretical analysis, but in the main part from my own experience of the process of creation. In this context they are closely linked to my personal feelings, impressions and emotional sensations accompanying, for example, the painting of pictures or taking photographs.

With regard to what is external and has been described and systematized by psychology or philosophy, with regard to his own experience, the creator remains alone. Loneliness in artistic creation is multi-dimensional. It exists, not turning into physical lone- 
liness thanks to self-awareness, emotional maturity and courage of the creator. Very often internal loneliness is ascribed to the unique personality disposition of the creator. In such cases a mythology of the artist's individualism is built. For the creator her/himself, loneliness is not a trivial thing adding variety to her/his life or a form of support for any secondary values. It is a matter of choice and therefore it becomes the most intimate area of the creative process, and the act of work or idea creation manifests itself in its essence as the joy of metaphysical encounter.

\section{REFERENCES}

Gadacz, T. (Ed.), (1995). O samotności. O spotkaniu. [About loneliness. About the meeting]. Cracow: Wydawnictwo ZNAK.

Piwocki, K. (1980). Dziwny świat współczesnych prymitywów. [A strange world of modern primitives]. Warsaw: Wydawnictwa Artystyczne i Filmowe.

Gorczyca, Ł. (1997). Od znaków do zmarszczek na twarzy. O obrazach i malarstwie Jarosława Modzelewskiego. [From marks to facial wrinkles. About picture and paintings of Jarosław Modzelewski]. Catalogue to the exhibition "Nieuchronne Zawężenie Pola Zainteresowań", Arsenal Gallery, Białystok.

Warpechowski, Z. (1996). Lecture delivered at the Faculty of Pedagogy and Psychology of the Warsaw University Branch in Bialystok on 25 May, 1996.

Kępiński, A. (2014), Melancholia [Melancholy], Cracow: Wydawnictwo Literackie.

Fromm, E. (2001). O sztuce miłości. [The Art of Loving]. Poznan: Dom Wyd. Rebis.

Schopenhauer, A. (2000). Aforyzmy o mądrości życia. [Aphorisms about the Wisdom of Life]. Warsaw: Wydawnictwo Czytelnik.

Szczepański, J. (1984). Sprawy ludzkie. [Human affairs]. Warsaw: Wydawnictwo Czytelnik.

Corresponding author at: Marzanna Morozewicz, Artistic Education Unit, Faculty of Education, University of Bialystok, 20 Świerkowa St., 15-328 Bialystok, Poland.

E-mail: mamo3@wp.pl www. mamo.art.pl 